\title{
Catching fish without a stick
}

\author{
Nguyen Thanh Thanh Huyen \\ Phenikaa University

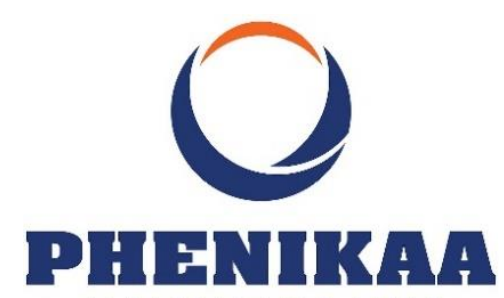

UN I VER S I T

January 29, 2021

Just a few weeks ago, I played "Animal Crossing: New Horizons" for the first time. My character was a teenage girl living on an isolated island full of animals who became my new neighbors. In my pocket, there were not so many tools. With a fishing rod and an aerial net to catch butterflies and bugs, I explored the island.

As my hands moved faster on the controller, the character quickly arrived at the beach. The sound of waves kissing the shore was so real. The golden sand made a whistling sound as I walked by. Something caught my attention, a big blackfish resting near the shoreline. Quickly pulling out my fishing rod, I asked my "mentor" for some advice to catch my prey.

"Don't swing the fishing rod too far from the fish, and quickly pull it back as soon as the fish eats the bait. Otherwise, it will swim away in a blink of an eye", he replied.

I pushed the button to throw the rod. The first attempt was a failure. The hook was not close enough to catch the fish's attention. I was quite sure that the hook should have stirred enough turbulence in the water that could scare the fish off, but it stayed there. I threw the rod again and again until the hook landed in the right zone. As soon as the fish swam towards the hook and disappeared in the water, I pushed the button to pull the rod back. The fish was on the other side of the rod.

If one has ever gone fishing, they might also find this experience nothing interesting compared to the real one. Going fishing is never only about catching fish, but also the time preparing and waiting. The game experience is so different from the experience I had when going fishing in real life. 
What I have when going fishing with my family is simple: a bamboo rod and a bag full of fat worms, sometimes pieces of meat. Sticking a worm properly to the hook is an art. The worm should be finely attached to hide the hook without being torn apart, which is not easy when the worm is alive. But even when the preparation is done properly, it never guarantees a reward.

Since the fish might come in a few seconds or never, I always hold the rod in my hands, waiting for the moment-the thought of giving up crossed my mind so many times, challenging my patience. However, an imaginary moment of having a fish on my hook is so attractive, and it keeps me believe that my patience will be rewarded. I keep the rod still, afraid that the fish will get scared if it moves. Perhaps, the longer the wait is, the happier I am when successfully fooling a tiny fish.

The reality just gives me a sense of what going fishing should be like. If using this as a standard, the experience I had in the game is so strange. A real fish would swim away as soon as I throw a hook near him. Still, the game is fun in a way that real fishing cannot be. I do not have to travel far just for fishing since the controller has everything I need: a rod and ponds with fishes.

Furthermore, no time is wasted for waiting in vain. Frankly speaking, as an amateur fisherman in real life, I have absorbed the new fishing culture of the digital environment [1].

Now that my colleagues invite me to go fishing, I would immediately think of the game instead of a real trip. In an era of unprecedented development in Vietnam [2], leisure time for fishing is scarce. For me, the contemporary culture of fishing is now a mixture of reality and the digital game [3].

Yet, the game cannot replace the real experience, at least, to the poet who immerses himself in nature like this:

"Ao thu lạnh lẽo nước trong veo,

Một chiếc thuyền câu bé tẻo teo.

Sóng biếc theo làn hơi gợn tí,

Lá vàng trước gió khẽ đưa vèo.

Tầng mây lơ lửng trời xanh ngắt,

Ngõ trúc quanh co khách văng teo.

Tựa gối, ôm cần lâu chẳng được,

Cá đâu đớp động dưới chân bèo."

Translations:

"The cool autumn pond, water so clear, How tiny it was, a fishing boat. 
The waves come, small, and so blue,

Withered leaves fall as the wind blows.

The blue sky above, clouds swim slow,

Lone winding valley rarely sees a guest.

Hands on knees, time passes, still empty,

Somewhere, a fish swims in the duckweed."

- Nguyễn Khuyến, Fishing in autumn -

\section{References}

[1] Vuong, Q. H. (2016). Global mindset as the integration of emerging socio-cultural values through mindsponge processes: A transition economy perspective. In $\mathrm{J}$. Kuada (ed.) Global Mindsets: Exploration and Perspectives (pp. 109-126). London: Routledge.

[2] Chính, P. M., \& Hoàng, V. Q. (2009). Kinh tế Việt Nam: Thăng trầm và đột phá. Nxb Chính trị Quốc gia, Hà Nội.

[3] Vuong, Q. H., et al. (2018). Cultural additivity: Behavioural insights from the interaction of Confucianism, Buddhism, and Taoism in folktales. Palgrave Communications, 4, 143. 